\title{
Clinical - Pathological Aspects of Hepatocellular Carcinoma in Cattle
}

\author{
Ana Paula Abreu Mendonça', Joselito Nunes Costa², Carmo Emanuel Almeida Biscarde ${ }^{3}$, \\ Luciano da Anunciação Pimentel2 \& José Carlos de Oliveira Filho²
}

\begin{abstract}
Background: The hepatocellular carcinoma (HCC) is a malignant neoplasm of hepatocytes of rare occurrence in farm animals, with ruminants being the most affected species. This neoplasm is characterized by nonspecific symptoms and it is etiology in animals has not yet been fully elucidated, although aflatoxin has been shown to be a risk factor in the development this neoplasia. Since hepatic tumors in cattle are commonly incidental findings found in postmortem examination, the objective of this paper is to describe the clinical, laboratory and pathological findings in a cow with this neoplasm.

Case: A 5-year-old, adult, Girolando cow weighing $350 \mathrm{~kg}$ was referred to the Veterinary Hospital of the Federal University of Recôncavo da Bahia, Brazil, with a history of decreased appetite and weakness for one month. The animal was raised in a semi-intensive system, with a corn-based diet, and regular vaccination. Futhermore, was not treated at the farm of origin and three days before being admitted to the hospital, began to present edema of the dewlap. On examination at our center, the cow was in lean, active, with mucupurulent secretion in nostrils; ocular conjunctiva edema; and edema of the dewlap. The cow had neutrophilia, hypofibrinogemia, hypoproteinemia, and trombocytopenia. It also had tachycardia, tense abdomen, engorgement of the vessels of the face and jugular veins, stasis test and bilaterally positive jugular pulse. Although evidence of pain in reticulum was negative in the examination, the initial diagnostic suspicion established was of traumatic reticular pericarditis. The therapeutic protocol instituted was daily monitoring, flunixin meglumine and flofernicol. The examination of rectal palpation revealed in the right flank an irregular-sized parenchymal structure with enlarged and palpacion in pain. Thus, by location and texture, it was suspected that the structure in question was a liver or kidney. However, the dosage of creatinine ruled out renal damage, and persistent hypoproteinemia reinforced the suspicion of hepatic impairment. In view the deterioration of the clinical condition and the suspicion of hepatic impairment, such as hepatic insufficiency, hepatitis or hepatic abscess, we opted for a right exploratory laparotomy. The surgery confirmed the presence of various granulomas throughout the liver, a non-luster organ, bulging edges with erosions and deposition of fibrin on the surface, confirming liver dysfunction. However, the animal died during the surgical procedure, and necropsy was performed, evidencing a focally extensive mass and multiple nodules of various sizes in the liver, lymph nodes and lung. In the microscopy of these nodules, cells similar to hepatocytes were observed, arranged in the form of strands or in agglomerates. Thus, similar to the reports in the literature, the diagnosis of HCC was carried out postmortem by necropsy and histopathology.

Discussion: The diagnosis of HCC was based on clinical, laboratory and anatomopathological findings. The hypoproteinemia and persistent hypofibrinogenemia suggest a hepatic dysfunction that was confirmed on surgery and histopathology. Primary liver tumors, although rare in production animals, must be considered in the differential diagnosis of weight loss, weakness and edema in cattle. It was not possible to determine the etiology of the neoplasia in this case, however, the possibility of aflatoxicosis by corn should not be ruled out as a probable inducer, since corn was a constituent of the diet provided to the animal.
\end{abstract}

Keywords: hepatic neoplasm, HCC, hepatopathy, farm animals, cow.

Descritores: neoplasia hepática, CHC, hepatopatia, animais de produção, vaca. 


\section{INTRODUCTION}

Although primary liver diseases are rare in farm animals, except for cases resultanting of intoxication [18], hepatocellular carcinoma (HCC) is the most frequent hepatic neoplasm in ruminants [15]. In cattle the reports are scarce $[6,10,12]$, most of them coming from slaughterhouses, thus not allowing much data from HCC in this species $[4,5,7,24]$.

$\mathrm{HCC}$ is a malignant neoplasm of hepatocytes with three forms of presentation: massive, nodular and diffuse [8] and with reports in different species like equine [17], buffalo [21], sheep [2,7,10]. It is an epithelial primary tumor in animals whose etiology is not fully understood and may involve both older cattle, and those under 3 years of age. Although not yet fully elucidated, HCC has been associated with carcinogens, such as aflatoxin and nitrosamines [26].

Similar to other liver diseases, HCC presents a non-specific symptomatology of progressive weight loss, anorexia and, in later cases, hepatomegaly and ascites. In some situations, there may be no evidence of any apparent hepatobiliary dysfunction in the animal, which makes it difficult to perform a diagnosis with the animal still alive or at an early stage $[6,9,16]$.

Thus, this paper describes clinical and histopathological aspects of HCC in cow. Once HCC is a malignant tumor with diagnostic difficulty [26], it is importante a description of the clinicopathologic findings for aid the clinical in the early diagnosis in cattle.

\section{CASE}

A 5-year-old female, Girolando cow weighting $350 \mathrm{~kg}$ was referred to the Veterinary Hospital of the Federal University of Recôncavo da Bahia, with a 1-month history of decreased appetite, weight loss and weakness. In addition, the animal presented swelling of the dewlap three days before being admitted to the hospital. The cow was raised in a semi-intensive system, with a corn-based diet, last parturiation five months ago, regular vaccination (Foot-and-mouth disease, rabies and brucellosis), and without any treatment performed at the farm of origin. On examination, although the body condition score (BCS) was 2.5 [BCS ranges from 1 to 5], the animal was active, with pink mucous membranes and normothermia. The cow had edema of the dewlab, engorgement of the vessels of the face, jugular veins, ocular conjunctiva edema, stasis test and positive jugular pulse, mucopurulent nasal secretion in both nostrils and tachycardia (heart rate, 85 beats per minute). With the exception of the slightly tense abdomen and faeces softened, changes in the another systems were not evidenced. Although the reticulum pain tests were negative, the initial diagnostic suspicion was of reticular traumatic pericarditis, and the therapeutic protocol was monitored daily, flunixin meglumine ${ }^{1}$ [Flunixin injetável, $1.1 \mathrm{mg} \mathrm{kg}^{-1}$, intramuscular] and florfenicol ${ }^{2}$ [Floroxin 30\%, $20 \mathrm{mg}$ $\mathrm{kg}^{-1}$, intramuscularly, 3 times every $48 \mathrm{~h}$ ].

Blood samples were collected by jugular venipuncture in Vacutainer siliconized tubes containing $10 \%$ EDTA $\left(\text { Vacuette }^{\circledR}\right)^{3}$ for measurements of blood count, total plasma protein (TPP), and plasma fibrinogen [11]. The complete blood count revealed hypoproteinemia of $4.2 \mathrm{~g} / \mathrm{dL}$ (reference range: 7-8.5); hypofibrinogenemia of $200 \mathrm{mg} / \mathrm{dL}$ (reference range: 300-700); thrombocytopenia of $186,000 / \mu \mathrm{L}$ (reference range: 200,000 - 730,000), and neutrophilia with 4.644/ $\mu \mathrm{L}$ (reference range: $600-4000$ ). The cow also presented presence of Anaplasma sp. in the blood smear and icteric plasma.

The examination of rectal palpation revealed in the right flank an irregular-sized parenchymal structure with enlarged and palpable pain. Thus, by location and texture, it was suspected that the structure in question was a liver or kidney. The creatinine dosage [13] $(0.77 \mathrm{mg} / \mathrm{dL})$ discarded renal damage, and persistent hypoproteinemia $(4.2 \mathrm{~g} / \mathrm{dL}, 5 \mathrm{~g} / \mathrm{dL})$ strengthened the suspicion of hepatic impairment.

In view the deterioration of the clinical condition and the suspicion of hepatic impairment such as hepatic insufficiency, hepatitis or hepatic abscess, we opted for a right exploratory laparotomy [25].

The surgery confirmed the presence of various granulomas throughout the liver, a non-luster organ, bulging edges with erosions and deposition of fibrin on the surface, confirming liver dysfunction. Necropsy revealed engorged vessels in the subcutaneous tissue of the abdominal wall, ascites and hydrothorax. Presence of fat deposits in the omentum and mesentery. In addition, multiple nodules in the lymph nodes and lungs, and a small area of adhesion between the liver and the abdominal cavity was observed (Figure 1A). It also had a focally extensive mass $30 \mathrm{~cm}$ in diameter in the liver, and multiple nodules of varying sizes (Figure 1B). The surface of the nodules was irregular, of a yellowishwhite color and crackling at the cut (Figure 1C e 1D). 


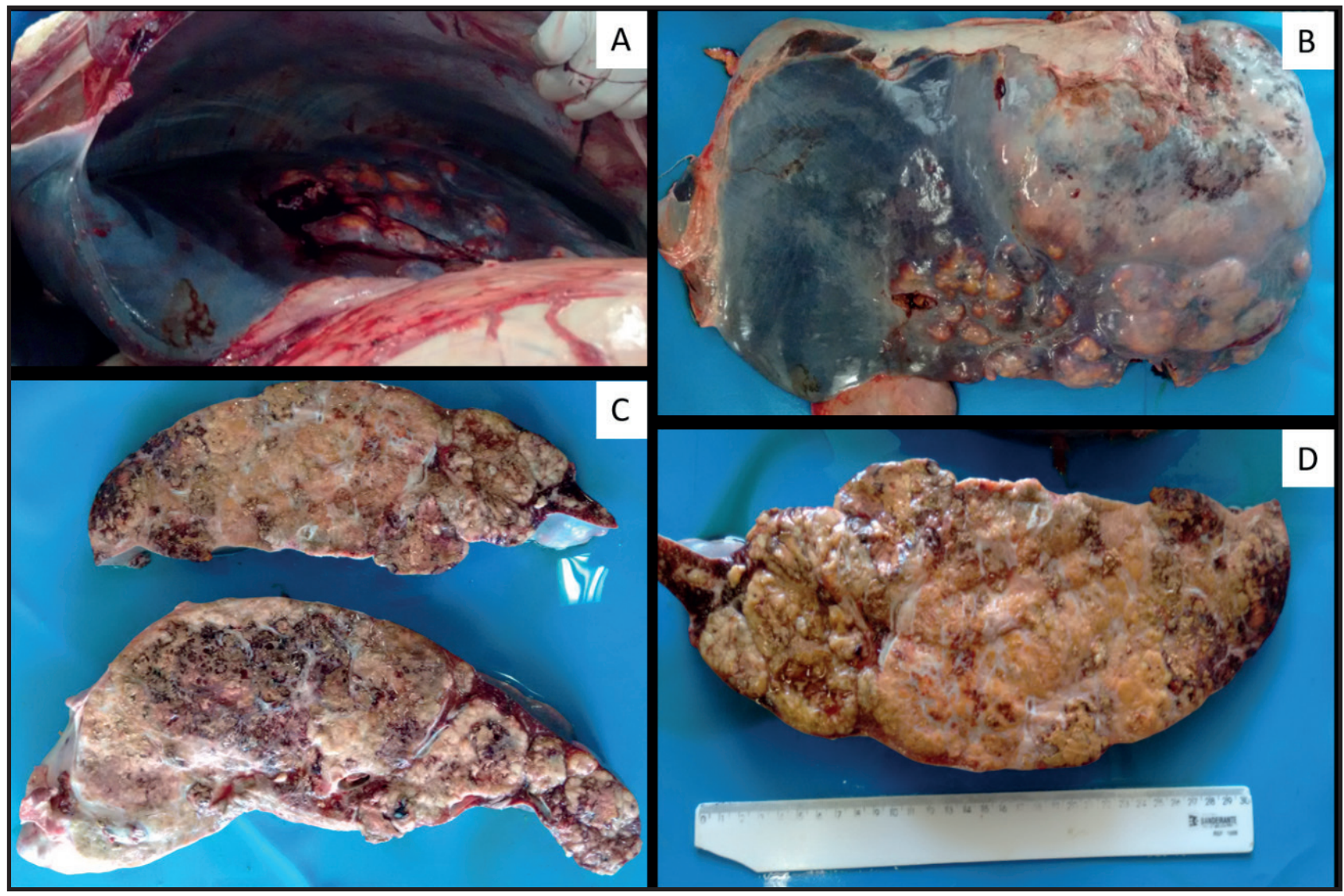

Figure 1. Macroscopic examination of the liver of a cow with CHC. A- Area of adhesion between the border of the liver and the abdominal wall. B- Liver with multiple nodules of varying sizes and irregular surface $\mathrm{C}$ - liver at the cut evidencing nodules that deepened and evidenced crackling. D- Cutting surface of liver tumor mass with irregular white - yellowed areas interspersed with fibrous tissue and areas with necrosis and hemorrhage.

Fragments of nodules in the liver, lung and lymph nodes were collected, fixed in $10 \%$ formaldehyde and routinely processed and stained with hematoxylin and eosin (HE) for histopathological evaluation.

Microscopic examination of the nodules showed tumor masses that consisted of hepatocyte-like cells with round nuclei; fragmented chromatin with evident nucleolus; discrete to moderate cytoplasm, and eosinophilic to pale (Figure 2A). The cells were arranged in the form of strands or in clusters delimited by a band of connective tissue with frequent mitoses. As a consequence of the compression of the various nodules, there were areas of necrosis and hemorrhage in the hepatic parenchyma (Figure 2B). In panoptic staining, predominance of small cells, evident nuclei (probably lymphocytes) and few cells of evident cytoplasm, some

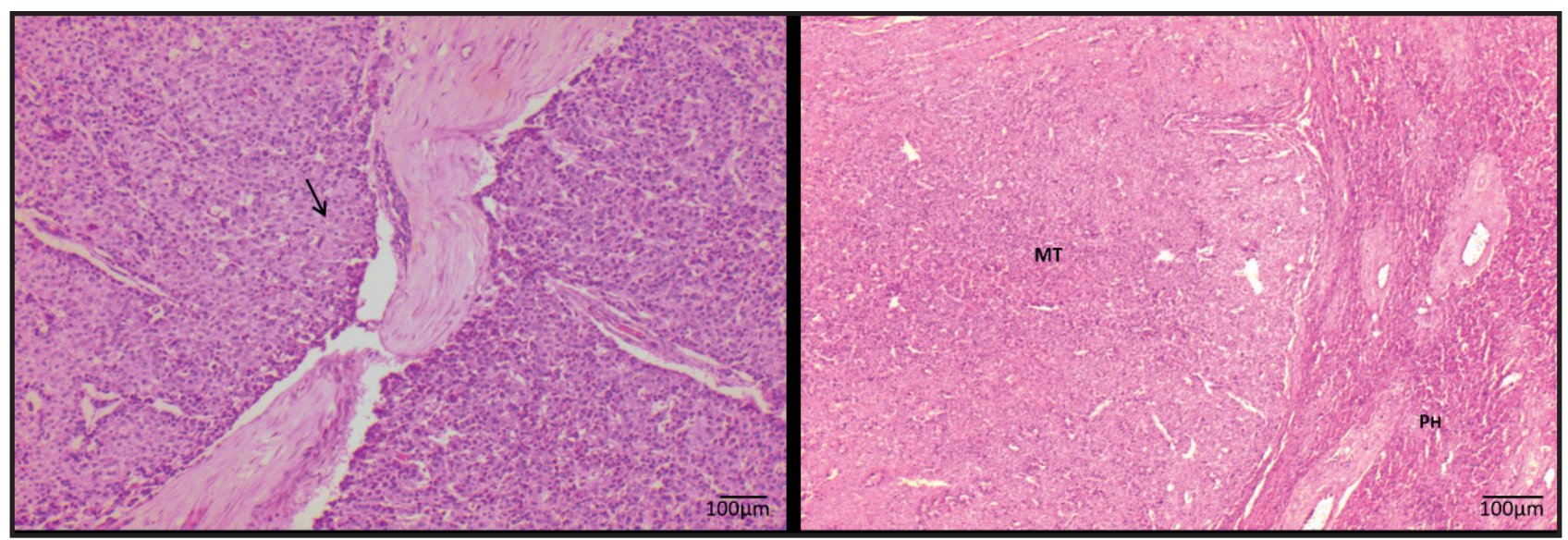

Figure 2. Histopathological examination of a cow with HCC. A- Color difference in hepatocyte cytoplasm (arrow) indicating possible cellular degeneration [HE; Obj.100x]. B- Tumor mass (MT) compressing the hepatic parenchyma (PH) [HE; Obj.100x]. 
of them, possibly hepatocytes. There was no presence of resistant acid alcohol bacilli in the Ziehl-Neelsen staining, ruling out the suspected tuberculosis, the main cause of lymphadenopathy in dairy cattle.

Based on the clinical, anatomopathological, and histopathological findings, the tumor was diagnosed to be a hepatocellular carcinoma with nodular pattern presenting with metastases to the lung and lymph nodes.

\section{DISCUSSION}

In bovines, HCC must be differentiated from other diseases that progressively lose weight and alterations of the digestive and cardiovasculares systems, especially reticulum traumatic pericarditis; tuberculosis associated with Mycobacterium bovis; and lymphomas associated with enzootic bovine leukosis virus $[2,19,27]$.

By the non-selective appetite and topographic anatomy of cattle, the reticulopericarditis traumatic should be considered as a differential diagnosis, even if the evidence of pain is negative [19].

Although the clinical condition of HCC, bovine leukosis and tuberculosis is similar, the histological appearance between them is quite different. In leukosis, it is common to observe clusters of neoplastic lymphocytes in organs [23], while in bovine tuberculosis it is possible to observe the presence of resistant acid alcohol bacilli in Ziehl-Neelsen staining, indicating the presence of Mycobacterium bovis [3], which was negative in the present report.

Unfortunately, a large part of the diagnosis of $\mathrm{HCC}$ in cattle is perfomed out postmortem, consisting mostly of incidental findings in the slaughterhouses $[5,7,12]$, with few reports on the clinical conditional of the animal. Consistent with the scarce reports available in the literature $[6,16]$, the main complaint of the owner of this report was progressive weight loss.

Although histopathology is the definitive diagnosis of this neoplasm, complementary tests such as hemogram, biochemistry, ultrasonography and urinalysis assist in the investigation of the case [9]. The biochemistry is a valuable test, since in bovines with $\mathrm{HCC}$ it is possible to observe serum increase of the liver enzymes [6], however, due to technical problems it was not possible to perform in this case. In the present study, severe hypoproteinemia, hypofibrinogenemia and thrombocytopenia were indicative of hepatic impairment [22].

According to macroscopic and histological pattern, the neoplasia of the present report can be classified as nodular and solid [8]. Metastases were observed in the lungs and lymph nodes, confirming what [2] affirm that these structures are the main targets for spreading the tumor.

From the authors' knowledge, the current paper is the first report of bovine death by HCC in Bahia to date. In this region liver tumors are not frequent, and most of the descriptions are related to the incidental findings of slaughterhouses [24]. However, the possibility of aflatoxin involvement in the carcinoma etiology of the present case can not be ruled out, since corn was part of the diet provided to the animal, and in Bahia have reports of contamination by this fungus in cereals used in animal feed [1,20].

The HCC, despite being of rare occurrence, should be considered in the differential diagnosis of progressive weight loss, appetite reduction, edema and hypoproteinemia in cattle. The anatomopathological pattern was conclusive for the diagnosis of nodular and solid hepatocellular carcinoma. Neoplasms of this type are often associated with metastases, making the prognosis unfavorable and might lead to animals' deaths.

\section{MANUFACTURERS}

${ }^{1}$ Chemitrex Saúde Animal. Ipiranga, SP, Brazil.

${ }^{2}$ Biogénesis Bagó Saúde Animal. Curitiba, PR, Brazil.

${ }^{3}$ Greiner Bio-One Produtos Médicos Hospitalares Ltda. Americana, SP, Brazil.

Declaration of interest. The authors report no conflicts of interest. The authors alone are responsible for the content and writing of paper.

\section{REFERENCES}

1 Almeida A.V.A.F., Botura M.B., Abreu R.D., Bittencourt T.C.C. \& Batatinha M.J.M. 2009. Ocorrência de aflatoxinas em milho destinado à alimentação de aves no estado da Bahia. Arquivos do Instituto Biológico. 26(3): 353-358.

2 Anderson L.J. \& Sandison A.D. 1968. Tumors of the liver in cattle, sheep and pigs. Cancer. 21(2): 289-301.

3 Andreazza D., Boos G.S., Boabaid F.M., Wouters A.T.B., Wouters F., Souza S.O., Menegat M.B. \& Driemeier D. 2015. Caracterização histológica e imuno-histoquímica das lesões de tuberculose em bovinos e de linfadenite granulomatosa em suínos. Pesquisa Veterinária Brasileira. 35(2): 129-136. 
4 Barbosa T.C., Cavalcante M.K.M., Damasceno E.S., Pachemshy A.S., Pachemshy C. \& Gouvêa F.H.F. 2013. Neoplasias hepatobiliares em bovinos: 11 casos. Archives of Veterinary Science. 18(2): 139-140

5 Bettini G. \& Marcato P.S. 1992. Primary hepatic tumours in cattle. A classification of 66 cases. Journal of Comparative Pathology. 107(1): 19-34.

6 Braun U., Nuss K., Soldati G. \& Ossent P. 2005. Clinical and ultrasonographic findings in four cows with liver tumours. Veterinary Record.157(16): 482-484.

7 Bundza A., Greig A.S. \& Dukes T.W. 1984. Primary Hepatocellular Tumors in Animals Killed at Meat Packing Plants: Report of 11 cases. Canadian Veterinary Journal. 25(2): 82-85.

8 Cullen J.M. \& Stalker M.J. 2016. Liver and Biliary System. In: Jubb, Kennedy and Palmer's Pathology of Domestic Animals. 6th edn. St. Louis: Elsevier, pp.258-352.

9 Ferrell L. \& Kakar S. 2007. Tumors of the liver, gallbladder, and biliary tree. In: Diagnostic Histopathology of Tumors. 3rd edn. London: Elsevier Limited, pp.417-435.

10 Gholami M.R., Hablolvarid M.H. \& Ezzi A. 2006. Hepatocellular carcinoma in sheep. Archives of Razi Institute. 61(1): 53-55.

11 Jain N.C. 1993. Essentials of Veterinary Hematology. Philadelphia: Lea \& Febiger, 417p.

12 Jeong W.I., Do S.H., Sohn M.H., Yun H.S., Kwon O.D., Kim T.H., Jeong D.H., Williams B.H. \& Jeong K.S. 2005. Hepatocellular Carcinoma with Metastasis to the Spleen in a Holstein Cow. Veterinary Pathology. 42(2): 230-232.

13 Kaneko J.J., Harvey J.W. \& Bruss M.L. 1997. Clinical Biochemistry of Domestic Animals. San Diego: Academic Press, 932p.

14 Lairmore M.D., Knights A.P \& Demartini J.C.1987. Three primary neoplasms in a goat: hepatocellular carcinoma, phaeochromocytoma and leiomyoma. Journal of Comparative Pathology. 97(3): 267-271.

15 Nourani H. \& Karimi I. 2007. Hepatocellular carcinoma in a sheep. Iranian Journal of Veterinary Research. 8(4): 368-369.

16 Ohfuji S. 2015. Hepatocellular carcinoma in a cow: detection of tumor-infiltrating T lymphocytes implicated in antitumor immune response and partial spontaneous tumor regression. Comparative Clinical Pathology. 25(2): 421-427.

17 Pereira C.M., Silva, P.E., Soares M.P., Sallis E.S.V., Grecco F.B., Raffi M.B., Fernandes C.G. \& Schild A.L. 2014. Doenças de equinos na região Sul do Rio Grande do Sul. Pesquisa Veterinária Brasileira. 34(3): 205-210.

18 Radostits O.M., Gay C.C., Blood D.C., Hinchcliff K.W. \& Peter D.C. 2007. Veterinary medicine. A textbook of the diseases of cattle, horses, sheep, pigs and goats. 10th edn. London: Saunders, 2065p.

19 Radostits O.M., Blood D.C., Gay C. \& Hinchcliff K.W. 2002. Clínica veterinária: Um tratado de doenças dos bovinos, ovinos, suinos, caprinos e eqüinos. 9.ed. Rio de Janeiro: Guanabara Koogan, pp.311-322 e 1524-1526.

20 Santos M.M. 2004. Ocorrência de fungos filamentosos e micotoxinas em bagaço de cevada destinado à alimentação do rebanho bovino leiteiro do estado da Bahia. 134f. Salvador, BA. Dissertação (Mestrado em Medicina Veterinária Tropical) - Escola de Medicina Veterinária, Universidade Federal da Bahia.

21 Selvam G., Swamy M. \& Verma Y. 2008. Hepatocellular carcinoma in an indian buffalo. Buffalo Bulletin. 27(1): 53-55.

22 Serakides R. \& Guedes R.M.C. 2004. Patologias do fígado. In: Serakides R. (Ed). Patologia Veterinária. Cadernos Didáticos. Belo Horizonte: FEPMVZN, pp.153-170.

23 Silva Filho A.P., Afonso J.A.B., Souza J.C.A., Riet Correa F., Dantas A.F., Dantas A.C., Costa N.A. \& Mendonça C.L. 2011. Linfossarcoma em bovinos no Agreste Meridional de Pernambuco. Pesquisa Veterinária Brasileira. 31(7): 591-597.

24 Tessele B. \& Barros C.S.L. 2016. Tumores em bovinos encontrados em abatedouros frigoríficos. Pesquisa Veterinária Brasileira. 36(3): 145-160.

25 Turner A.S. \& MeIlwraith C.W. 1985. Técnicas Cirúrgicas em Animais de Grande Porte. São Paulo: Roca, $341 \mathrm{p}$.

26 Valentine B.A. 2004. Neoplasia. In: Fubini S.L. \& Ducharme N.G. (Eds). Farm Animal Surgery. 2nd edn. St Louis: Saunders, pp.119-120.

27 Wettimuny S.G.S. 1969. Primary liver tumours of cattle in Ceylon. Journal of Comparative Pathology. 79(3): 355-365.

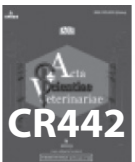

